\title{
Modeling Effects of KM and HRM Processes to the Organizational Performance and Employee's Job Satisfaction
}

\author{
Azizur Rahman ${ }^{1} \&$ Najmul Hasan ${ }^{2}$ \\ ${ }^{1}$ Charles Sturt University, Wagga Wagga NSW, Australia \\ ${ }^{2}$ Technotex Solutions Limited Dhaka, Bangladesh \\ Correspondence: Azizur Rahman, School of Computing \& Mathematics, Charles Sturt University, Wagga Wagga \\ NSW 2678, Australia. E-mail: azrahman@csu.edu.au
}

Received: November 5, 2016

Accepted: May 25, 2017

Online Published: June 7, 2017

doi:10.5539/ijbm.v12n7p35

URL: https://doi.org/10.5539/ijbm.v12n7p35

\begin{abstract}
There have been many literature focusing on Knowledge Management (KM) contribution to the business world, and there is still a lacuna of empirical studies related to KM and Human Resource Management (HRM) practices. This paper examines the effects of KM and HRM practices relating to the organizational performance and employee's job satisfaction level. A theoretical model is proposed to identify significant relationships and to develop some hypothesis. These hypotheses are then tested with a structural equation modeling using a randomly selected survey data set of 150 respondents, where variables in the questionnaire have been considered from previous empirical studies. Results demonstrate significant positive effects of KM and HRM practices to the organizational performance. Finding also reveals that employee's loyalty to the organization depends on employee's job satisfaction which is highly influenced by the organizational performance. Although the sample is limited to a Bangladeshi organization, the new model can be employed to datasets from other developing countries.
\end{abstract}

Keywords: HRM Practice, Job Satisfaction, KM activities, Organizational performance, Bangladesh

\section{Introduction}

Knowledge management (KM) has achieved topics of interest in both academic and business world. The process by which capture and share knowledge by managerial personal with the help of information and communication technology (ICT) can be define knowledge management (Huysman \& De Wit, 2004; Mia \& Hasan, 2016). Organizations are changing tremendously practicing new knowledge and creating opportunities for their employees. Also academic personal keep the place of practicing KM as well as business world. On the other hand human resource management (HRM) is very much important part of an organization to better understanding of preparation of business environment and practicing existing KM (Rao, Mansingh, \& Osei-Bryson, 2012).

Human resource management (HRM) with the help of knowledge management (KM) and organizational performance as well as employee's job satisfaction have strategic positive relationship and a buzzword in academic and business world over the past few decades. At the same time knowledge management (KM) on the HRM practice is a curtail issue for organizational performance now a days (Nielsen et al., 2011). Combination of HRM practice and KM has a positive relationship on organizational performance (Jimenez-Jimenez \& Sanz-Valle, 2012; Runar Edvardsson, 2008). Across the world it has been set that a person having higher level job satisfaction feel positive exposure to the job (Islam et al., 2011). On the contrary, a dissatisfied person possesses negative treatment towards the job. According to Stephen P \& Mary Coulter (2004) people talk about the attitude of the employee, they generally refer to the job satisfaction. In fact, Brief and Weiss (2002) stated that job satisfaction is a state of positive emotion deriving from the individual's job appraisal or his/her experience regarding job. In this case arguably, the theory of range of affect Theory is very famous model in job satisfaction.

Numerous types of job characteristics are assessed to observe to what extent employees differentially value various aspects of their jobs. According to Hodson (1989) these characteristics include occupational prestige, earnings, education, job complexity, level of authority exercised, how closely the worker is supervised, job 
pressure, being held responsible for things outside one's control, how frequently one has to get dirty on the job, being underemployed, workplace size, and level of optimism about one's future at the current job (Ali \& Akhter, 2009). Relationship with the supervisor is also an important factor influencing the employees. According to Herzberg et al., (1957), it is a hygiene factor that may lead to job dissatisfaction. Employees' in organizations are often attracting their supervisors for different reasons. These relationships are called functional and entity relationships (Brief \& Weiss, 2002). Functional relationships between supervisor and subordinate are based on which services can be provided for each other. These values are normally related, or are related to the rewards the employee can accrue for task performance. Again, welfare programs including benefits, bonus, overtime, transport allowance, medical allowance, etc., have positive relationships with job satisfaction of employees (Ali \& Akhter, 2009).

Literature states that satisfaction is mainly determined by an incongruity between one's expectation from a job and what actually one got. The early form of job fulfillment mentioned that all segments of one's work surroundings contributed in additive approach to the overall job satisfaction. Actually, job satisfaction is treated as a factor of organizational obligation (Moorman, Niehoff, \& Organ, 1993). It can be considered as a global concerned about job and related attitudes constellation on facets of the respected job (Ali \& Akhter, 2009). Evidently stated moods are generally related to the overall job satisfaction. Both positive and negative emotions to be found significantly because it is related to the overall job satisfaction (Fisher, 2000). Guerra and Patuelli (2014) argued that various studies indicated dissatisfied employees are reluctant to quit their job or even became absent rather than satisfied employees.

The main objective of this study is to identify and justify factors relationship between organizational performance as well as employee's satisfaction on the basis of practicing HRM and KM. additionally we will try to find some important manifest variables based on the previous empirical studies will show how HRM and KM effects to job satisfaction of the employee. On the other hand in broad sense study will helps professional to better understand and they might use as guide in many academic or business world regarding the relationship of organizational performance as well as employee's job satisfaction by the effect of KM activities combined with HRM practice.

The structure of the paper is as below. Section 2 provides a brief image on the previous study of the literature where we try to find effectiveness of KM and the relationship between KM and HRM practice. On the other hand in this section we also found some factor and manifest variable based on past literature related to KM and HRM as well as job satisfaction and job loyalty. In section 3 we proposed research model of the relationship among KM, HRM practice on Organizational performance and job satisfaction and we build some hypothesis based on our problems also define research methodology and describe sample selection process. In section 4 we describe the data analysis, checked data reliability and validity using structural equation modeling. At the end of the paper we made in depth discussion and provide few recommendations for future studies and batter use of this study for academic and business perspective.

\section{Background of the Study}

\subsection{Knowledge Management Effectiveness (KME)}

During learning process in the organization when stock of knowledge implemented to acquire and gather for the organization such as innovation capital and all the components are to be implemented within the organization can be define knowledge management (Cricelli, Grimaldi, \& Hanandi, 2012; Villar, Alegre, \& Pla-Barber, 2014). On the other hand definition of KM can be considered as a broad sense. In the present business world KM has achieved popularity in both commercial and academic arenas. With the help of advanced information and communication technology (ICT) KM makes organization within a hand. Some components like knowledge sharing (Hau, Kim, Lee, \& Kim, 2013; Zhou \& Li, 2012), Data-mining \& Decision tool (Silwattananusarn \& Tuamsuk, 2012), Innovative skills (Mia \& Hasan, 2016) etc. have modified KM in new looks. According to Tan and Nasurdin (2011) "knowledge management is defined as the deployment of a comprehensive system that enhances the growth of an organization's knowledge" which can be focused the development of strategic business objective. KM can be classified into various ways such as explicit and implicit as well as tacit knowledge (Hau et al., 2013). Explicit knowledge is more popular now a day with the help of ICT which makes $\mathrm{KM}$ to gather and implementing various types of knowledge in easier ways. Effectiveness of the KM can be analyzed in process perspective which conceived the process of developing and achieving organizational innovation for increasing business scope and make HRM perfect which helps to achieve turnover profitable (Cricelli et al., 2012; Runar Edvardsson, 2008). In the next session we will examine the KM practice on HRM and also look what types of support KM gives on HRM effectively and efficiently on employee's satisfaction. 


\subsection{Knowledge Management and Human Resource Management}

There have been many significant studies that examined the relationship between effective KM activities and practicing HRM. For instant Brewer and Brewer (2010) and Gloet (2006) found positive significant relation of KM and HRM practices. On the other hand interaction between KM and HRM has been increasing rapidly in recent years. Numerous organizations are now engaging collective knowledge and collaboration of their employees in capturing and sharing knowledge make as a competitive tools by which innovation can encourage, support and reward among between people (Beardsley, Johnson, \& Manyika, 2006). The exploration of HRM practicing has greater emphasis on explicit knowledge where information technology has big contribution to achieve capturing and sharing knowledge (Hislop, 2002). According to Runar Edvardsson (2008) there are two former strategies named "codification" and "personalization" to managing knowledge. But nowadays concept of practicing KM is modified. Organizations are heavily invested to ICT sector and make data warehouse with knowledge mapping note and data mining tools. Organization's personal are using these knowledge effectively and increase their efficiency for organizational performance. The rapid use of knowledge with the help of easy access to the KM employees is able to cut working time, reduce cost of communication and able to solve complex problem. Hansen, Nohria, and Tierney (1999) and Runar Edvardsson (2008) both gives evidence on relationship of KM and HRM and described KM not only the way of apply strategies to fill the organization's objective but critical ingredient of competitiveness and they provide evidence of KM and HRM practicing at least two point of view; Recruitment and selection, Training and development and Gloet (2006) provided information on developing leadership and management capabilities to support sustainable goal across business world linking KM and HRM. Towards the end executive managers need to understand of KM activities in various organizational structure, culture, HR as well as technology for successful implementation of KM. Especially, HR became one of the critical factors for effective KM. Armstrong (2006) characterizes HRM as a vital and sound way to deal with the administration of an association's most esteemed resources - the individuals working there who separately and altogether adds to the accomplishment of the destinations. HRM includes all administration choice and practices that specifically influences the individuals, or HR, who work for the association (Schuler \& Jackson, 1987).

The Job Descriptive Index (JDI) popularly has known as measure of job satisfaction in terms of five various aspects of a person's job. They are included pay, promotion, supervision, the work itself, and co-workers (Crossman \& Abou-Zaki, 2003). There is even some evidence that job satisfaction positively influence organizational citizenship behavior (Guerra \& Patuelli, 2014).In academic viewpoint, Clarke and Keating (1995) found out that interaction with students was the most satisfying aspect for teachers, while lack of administrative support was the least satisfying aspect. Crossman and Abou-Zaki (2003) also found that teachers are most satisfied with their co-workers and least satisfied with monetary aspects of teaching.

Studying the factor that affect job satisfaction the literature of current study referred to those factors that are very close to organization's turnover that shows that dissatisfied employee more likely to switch from there institutions. This is also studied from previous research in other disciplined like management, Marketing and in organizational behavior shown that HR practices are primary indicator of job satisfaction to the work (Maidani, 1991). In addition some time job satisfaction use as intervening variable. In addition table 1 shows our searched variable related to the study provide evidence from previous literature.

Table 1. Variable considered for study are based on previous literature

\begin{tabular}{|c|c|c|}
\hline & $\begin{array}{l}\text { Employee's always } \\
\text { have intention to }\end{array}$ & $\begin{array}{l}\text { (Lindner \& Wald, 2011); (Gloet, 2006); (Mia \& Hasan, 2016); (Salisbury, 2003); (Zhou \& Li, 2012); } \\
\text { (Villar et al., 2014); (Huysman \& De Wit, 2004); (Bock, Zmud, Kim, \& Lee, 2005); (Zucker, Darby, }\end{array}$ \\
\hline KM1 & Knowledge sharing & \& Armstrong, 2002); (Prihandinisari, Rahman, \& Hicks, 2016) \\
\hline KM2 & $\begin{array}{l}\text { Sufficient to support the } \\
\text { daily work }\end{array}$ & \\
\hline KM3 & $\begin{array}{l}\text { Staff } \quad \text { Member } \\
\text { Motivation }\end{array}$ & \\
\hline KM4 & Knowledge encouraging & \\
\hline KM5 & Knowledge Capturing & \\
\hline & $\begin{array}{l}\text { Employee's always } \\
\text { have satisfaction on }\end{array}$ & $\begin{array}{l}\text { (Clarke \& Keating, 1995); (Crossman \& Abou-Zaki, 2003); (Gloet, 2006); (Hau et al., 2013); } \\
\text { (Jimenez-Jimenez \& Sanz-Valle, 2012); (Runar Edvardsson, 2008) }\end{array}$ \\
\hline HRMP1 & Supervision Practice & \\
\hline HRMP2 & Team Building & \\
\hline
\end{tabular}




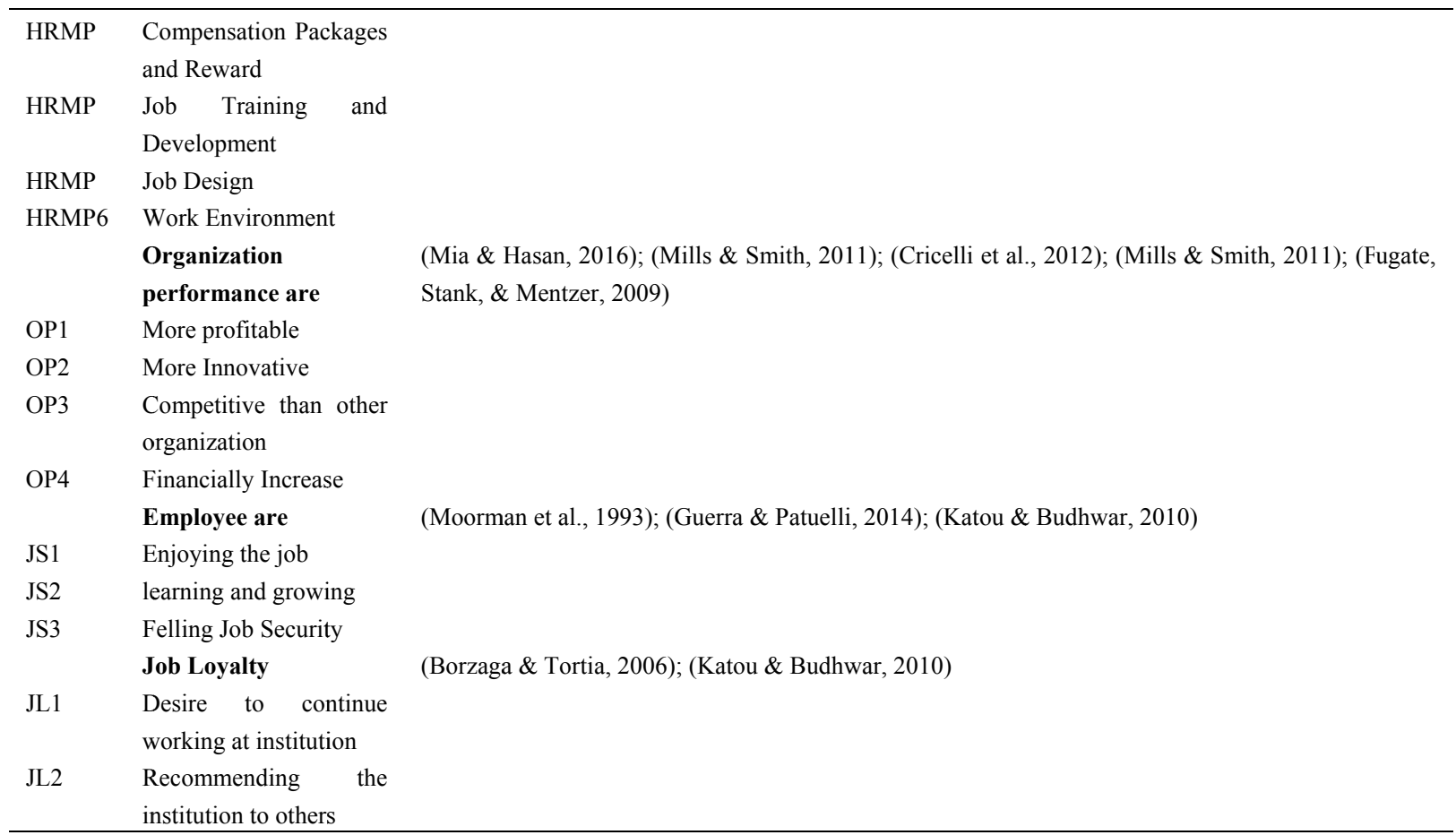

\section{Research Model and Proposed Hypothesis}

Figure 1 indicates the proposed research model of the relationship among the KM and HRM practice on organizational performance and job satisfaction. From the model we may able to find both direct effect and indirect effect of the KM practice to organizational performance. Otherwise practicing HRM with help of KM what is the effect on organizational performance. Also we will see the effect of employee's job satisfaction and how is the intention to stay in organization in future.

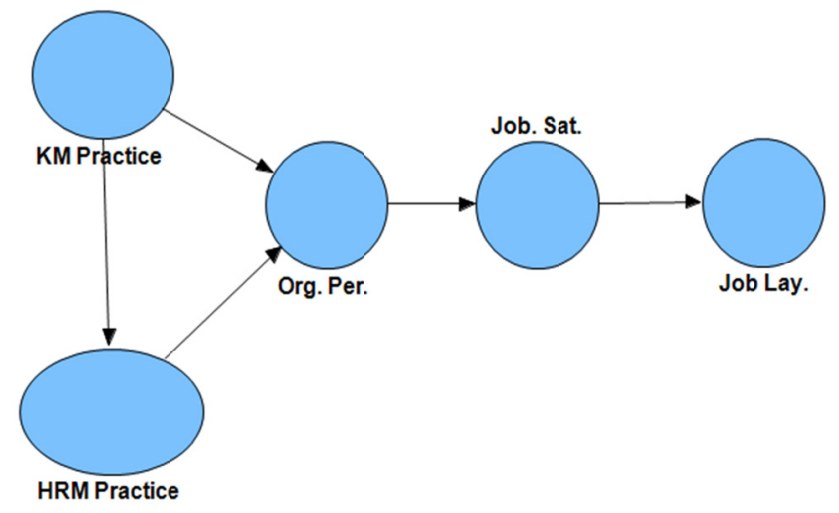

Figure 1. Nexus of KM and HRM practices to the organizational performance and employee's job satisfaction and loyalty

\subsection{Hypothesis}

$\mathbf{H}_{\mathbf{0}}$ : There is no significant relation between $\mathrm{KM}$ practices on organizational performance

$\mathbf{H}_{1}$ : There is significant relation between $\mathrm{KM}$ practices on organizational performance

$\mathbf{H}_{2}$ : There is significant relation between HRM practices on organizational performance

$\mathbf{H}_{3}$ : There is significant relation between HRM practices on organizational performance

$\mathbf{H}_{4}$ : There is significant relation between Organizational performances on job satisfaction

$\mathbf{H}_{5}$ : There is significant relation between job satisfactions on job loyalty 


\subsection{Methodology and Sample Selection}

We derived the items of KM and HRM practice from reviewing past literature. For example KM items were retrieved from (Lindner \& Wald, 2011; Mas-Machuca \& Martínez Costa, 2012; Mia \& Hasan, 2016; Zheng, Yang, \& McLean, 2010) and HRM items from (Arumugam \& Mojtahedzadeh, 2011; Khan, Hasan, \& Rubel, 2015; Moideenkutty, Al-Lamki, \& Sree Rama Murthy, 2011). There are many on growing and established innovative company over Bangladesh including all big cities like Dhaka, Chittagong etc. the sample of the study were taken from employee of those organization. Maintaining Gasquet, Falissard, and Ravaud (2001) method we provided 750 questionnaire to the various level of employee and we got 167 return. So the response rate is approximately 22 percent. But after scrutinize we avoided some 17 due to data error and finally 150 questionnaire were selected for data analysis. To examine our proposed model we conducted both exploratory and confirmatory factor analysis with the help of smart PLS.

\section{Results and Discussion}

To test the hypothesis about the relationship of latent variable and observed variable most uses approach is structural equation modeling (SEM) which combined the feature of factor analysis and multiple regression analysis. With the help of SmartPLS observation between latent variable and relationship between latent variable and associated items were examined which are the main two model of SEM called inner model and outer model. The relationship between latent variables is in table 2

Table 2. Outer loading and convergent validity and construct reliability

\begin{tabular}{|c|c|c|c|c|c|c|c|c|}
\hline \multirow[b]{2}{*}{$\begin{array}{l}\text { Latent } \\
\text { variable }\end{array}$} & \multirow[b]{2}{*}{ Items } & \multirow[b]{2}{*}{ Loading } & \multirow[b]{2}{*}{ Weight } & \multicolumn{4}{|c|}{ Convergent Validity and Construct Reliability } & \multirow[b]{2}{*}{ Communality } \\
\hline & & & & Average & $\begin{array}{l}\text { Composite } \\
\text { Reliability }\end{array}$ & R Square & $\begin{array}{l}\text { Cronbach's } \\
\text { Alpha }\end{array}$ & \\
\hline \multirow{7}{*}{ 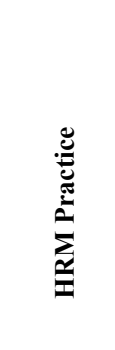 } & HRMP1 & 0.4367 & 0.1149 & \multirow{5}{*}{0.3774} & \multirow{5}{*}{0.7749} & \multirow{5}{*}{0.0818} & \multirow{5}{*}{0.7287} & \multirow{5}{*}{0.3774} \\
\hline & HRMP2 & 0.3919 & 0.0239 & & & & & \\
\hline & HRMP3 & 0.6764 & 0.2447 & & & & & \\
\hline & HRMP4 & 0.7766 & 0.3608 & & & & & \\
\hline & HRMP5 & 0.5848 & 0.2674 & & & & & \\
\hline & HRMP6 & 0.7194 & 0.4703 & \multirow{6}{*}{0.6079} & \multirow{6}{*}{0.8848} & \multirow{6}{*}{0} & \multirow{6}{*}{0.8517} & \multirow{6}{*}{0.6079} \\
\hline & KM1 & 0.7784 & 0.2070 & & & & & \\
\hline \multirow{4}{*}{ 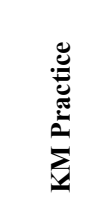 } & KM2 & 0.8562 & 0.3870 & & & & & \\
\hline & KM3 & 0.7777 & 0.1151 & & & & & \\
\hline & KM4 & 0.8252 & 0.4145 & & & & & \\
\hline & KM5 & 0.6439 & 0.1179 & & & & & \\
\hline \multirow{4}{*}{ 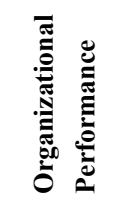 } & OP1 & 0.7471 & 0.2858 & \multirow{4}{*}{0.6478} & \multirow{4}{*}{0.88} & \multirow{4}{*}{0.3873} & \multirow{4}{*}{0.8183} & \multirow{4}{*}{0.6478} \\
\hline & OP2 & 0.8221 & 0.2725 & & & & & \\
\hline & OP3 & 0.7732 & 0.3044 & & & & & \\
\hline & OP4 & 0.8715 & 0.3753 & & & & & \\
\hline \multirow{5}{*}{ 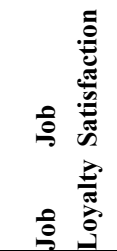 } & JS1 & 0.881 & 0.3833 & \multirow{3}{*}{0.7491} & \multirow{3}{*}{0.8996} & \multirow{3}{*}{0.2544} & \multirow{3}{*}{0.8328} & \multirow{3}{*}{0.7491} \\
\hline & JS2 & 0.8607 & 0.3601 & & & & & \\
\hline & JS3 & 0.8546 & 0.4124 & & & & & \\
\hline & JL1 & 0.9007 & 0.5826 & \multirow[t]{2}{*}{0.7951} & \multirow[t]{2}{*}{0.8858} & \multirow[t]{2}{*}{0.3408} & \multirow[t]{2}{*}{0.7427} & 0.7951 \\
\hline & JL2 & 0.8826 & 0.5385 & & & & & \\
\hline
\end{tabular}

In PLS reliability of the individual teams is assessed by the factor loading with their respective contrast. Many researchers accept the factor loading more than 0.50 which implies that there is more variance between contrast and their respective items than error variance. In our study most of the outer loading more than 0.50 and positive. So we may conclude that items of the latent variables are good measure with their respective contrast. On the other hand Cronbach's Alpha indicates the data reliability and from table 2 all the values greater than 0.70 which indicates that collected data were very much reliable. 
Most of the constructs had higher loadings except item first two of HRM practice also in table 2 (HRMP1 \& HRMP2). These had lower positive loading (0.436 and 0.391) than that of loading for the other factor which had a high positive loading. Discriminant and divergent validity were thus achieved. Convergent Validity on requirements was also significant as all items had an eigenvalue above one $(>1.0)$ and the loading higher than 0.50 on their particular factors. Convergent validity was therefore achieved. Discriminant validity was evaluated by examining whether each item loaded higher on the construct it measured than on any other construct.

On the other hand it is important that all the relationship between the latent variable in the model should be positive. Therefore, for each regression model, an increase in the value of an independent latent variable will also increase the value of related dependent latent variable. Based on the outcome factors of organizational performance explains it has very little impact directly by KM practice whereas indirect effect of organizational performance with the concern of HRM practice is positively indicates approximately 62 percent of the variation of HRM practice whereas organizational performance has 38 percent variability. Again overall employee's job satisfaction explains 25 percent variability of organizational performance and job satisfaction explains 34 percent variability of employee loyalty. According to the model the five hypothesis we built in the conceptual model and the relation are confirmed.

Again average and construct reliability also showed in the above table. Traditionally Cronbach's alpha indicates reliability of the measurement model which all are above 70 percent and average can be accepted when the values are greater than 0.50. But if the values of Cronbach's alpha is greater than 0.70 and reliable. Again according to James Gaskin, (2012) also suggest the communalities greater than 0.50 also reliable for the data. Hence our study fill all the requirement mostly.

Table 3. Discriminant validity

\begin{tabular}{|c|c|c|c|c|c|}
\hline \multicolumn{6}{|c|}{ Discriminant Validity } \\
\hline & HRM Practice & Job Loyalty & Job Satisfaction & KM Practice & $\begin{array}{l}\text { Organizational } \\
\text { Performance }\end{array}$ \\
\hline HRM Practice & 0.6143 & & & & \\
\hline Job Lay. & 0.5364 & 0.8917 & & & \\
\hline Job. Sat. & 0.4419 & 0.5838 & 0.8655 & & \\
\hline KM Practice & 0.286 & 0.4075 & 0.4783 & 0.7797 & \\
\hline Org. Per. & 0.6223 & 0.4567 & 0.5044 & 0.1817 & 0.8049 \\
\hline
\end{tabular}

The above table also showed the validity according to the PLS-SEM. Actually explanation of discriminant validity indicates how much variance of the indicators which are explain variance to the contrast. Calculation of discriminant validity is done by the square root of the AVE value. In the above table the diagonal elements are the square root of the respective AVE values and in this study we were able to achieve the proper values.

\subsection{Reliability of Parameter Estimates}

Another test statistics is the $t$-statistic which indicates the parameter estimate divided by its standard error (S.E.). As a "rule of thumb" the $t$-statistic needs to be $>1.96$ or $<-1.96$ fit the estimate is acceptable. The results showed that all the $t$-statistic values were greater than 1.96, except KM Practice > Organizational Performance, indicating that they were all acceptable. 


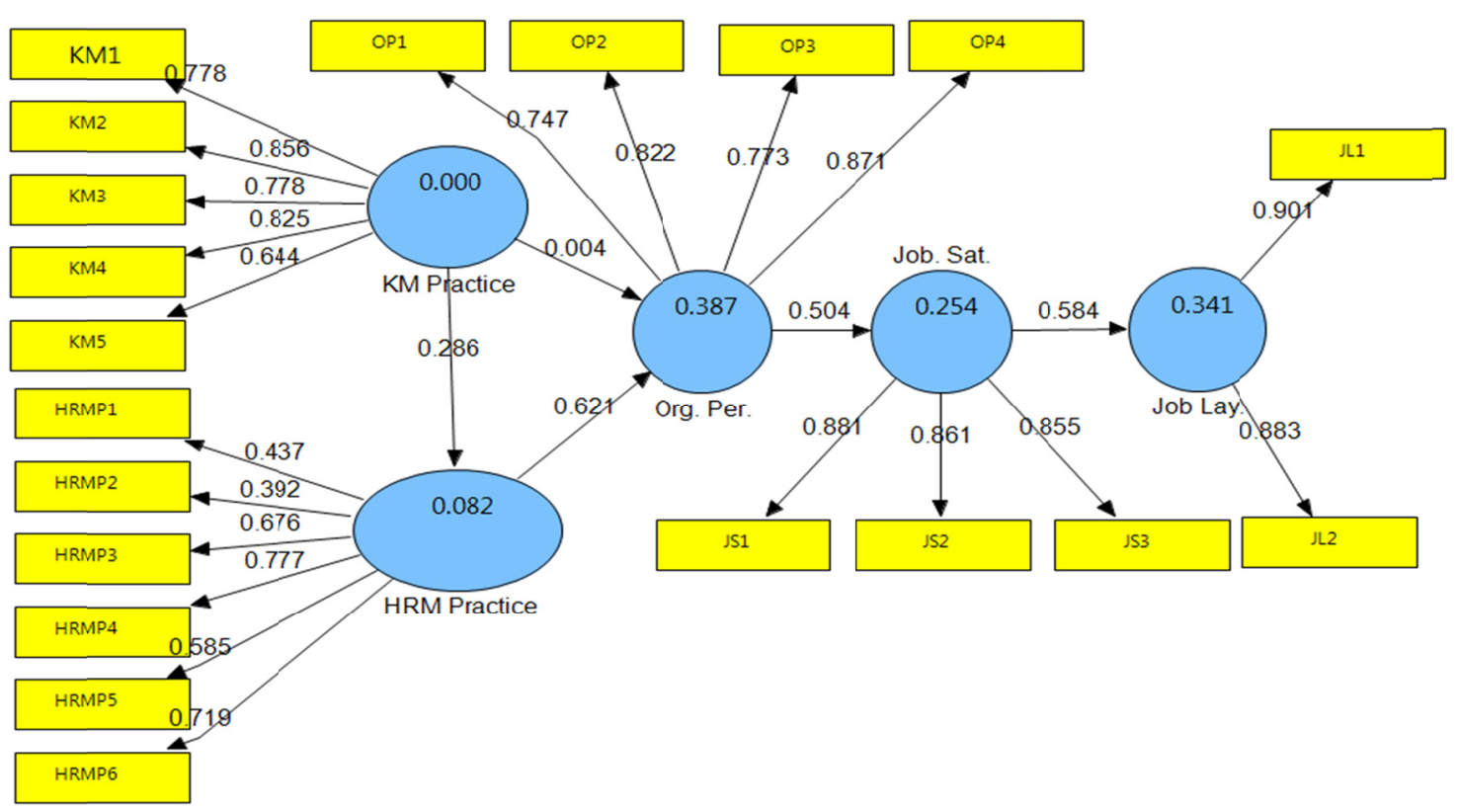

Figure 2. PLS algorithm: outer loadings

Results, appendix 1, show the t-test scores to compare the two conditions. Respondent have more intention to stay in present organization if they are satisfied in their job compared with organizational performance. This can perceived that job loyalty heavily depends on job satisfaction and on the other hand organizational performance depends on KM activities combination with HRM practice.

Table 4. Hypothesis testing

\begin{tabular}{lllll}
\hline Hypothesis & Path & $\boldsymbol{\beta}$ & $\boldsymbol{t}$-Statistics & Comments \\
\hline $\mathbf{H}_{\mathbf{1}}$ & KM Practice -> Organizational Performance & 0.004 & 0.0452 & Not Supported \\
$\mathbf{H}_{\mathbf{2}}$ & KM Practice-> HRM Practice & 0.286 & 2.2809 & Supported \\
$\mathbf{H}_{\mathbf{3}}$ & HRM Practice -> Organizational Performance & 0.621 & 7.7496 & Supported \\
$\mathbf{H}_{\mathbf{4}}$ & Organizational Performance -> Job Satisfaction & 0.504 & 6.2092 & Supported \\
$\mathbf{H}_{\mathbf{5}}$ & Job Satisfaction-> Job Loyalty & 0.584 & 6.6605 & Supported \\
\hline
\end{tabular}

\section{Conclusion}

This study provides significant evidence that the fact of KM practice and HRM practices carried out in developed and developing organization in Bangladesh through structural equation modeling conducted and tested five alternative hypotheses to determine how these variables are interrelated. The results of study represent that employees were satisfied of practicing KM with the help of HRM. The employees were satisfied with Job training, work environment and job design as well as job security and compensation packages whereas expressed little satisfaction with supervision practice and team building practices. If organization provides better job security and well work environment, physical and cultural, for their stuff they will become more satisfied with their job.

As per our model we found that expectancy of organizational performance had a positive effect on employee's job satisfaction but we found a little effect of KM practice directly. On the other hand indirect effect of KM practice through HRM practice had great contribution to organizational performance indirectly. So only HRM practice in the organization may not fill expectancy level of the organization. Also we found employee's job loyalty had significant effect on job satisfaction level and figure 2 showed factor loading of staying in present organization is very high $(>0.90)$.

Organization must focus on providing favorable environment to support daily work by which they may create, capture and share their knowledge. Organization should encourage their employee to capturing the knowledge 
from their daily activity and some stuff member should be motivated by the gainer or who are in the leading position or who practicing KM. On the other hand HRM activities and program like team building, job design, employee's training and development, reward on performance etc. are to maintain for the improvement of organizational performance. Business organization must identify their pores and corns from their daily activities and implement using HRM components to the organization or the member of the organization so that overall performance must benefited as well as financially improved. Because employee's job satisfaction depends on the organizational performance and employee are willing to stay in the present organization. Additionally, all types of organizations; commercial or noncommercial, need people committed to lifelong learning in order to sustain and improve their knowledge bases. The future research will explore a Bayesian analysis-based (Rahman et al., 2016) microsimulation modeling approach (Rahman, 2016; Rahman \& Harding, 2016) of HRM and labour market dynamics including job satisfaction.

\section{Acknowledgements}

The authors would like to sincerely thank two anonymous reviewers and the editor for their stimulus and valuable comments, which were used to form the final version.

\section{References}

Ali, T., \& Akhter, I. (2009). Job satisfaction of faculty members in private universities-in context of Bangladesh. International Business Research, 2(4), 167-175. http://dx.doi.org/10.5539/ibr.v2n4p167

Armstrong, M. (2006). Strategic human resource management: a guide to action. London: Kogan Page Ltd.

Arumugam, V. C., \& Mojtahedzadeh, R. (2011). The impact of human resource management practices on financial performance of Malaysian industries. International Research Journal of Finance and Economics, $80,49-54$.

Beardsley, S. C., Johnson, B. C., \& Manyika, J. M. (2006). Competitive advantage from better interactions. McKinsey Quarterly, 2, 52-63.

Bock, G.-W., Zmud, R. W., Kim, Y. G., \& Lee, J. N. (2005). Behavioral intention formation in knowledge sharing: Examining the roles of extrinsic motivators, social-psychological forces, and organizational climate. MIS quarterly, 87-111-123. Retrieved from http://www.jstor.org/stable/25148669

Borzaga, C., \& Tortia, E. (2006). Worker motivations, job satisfaction, and loyalty in public and nonprofit social $\begin{array}{lllll}\text { services. Nonprofit and voluntary sector quarterly, } & 35(2), & \text { 225-248. }\end{array}$ https:/doi.org/10.1177/0899764006287207

Brewer, P. D., \& Brewer, K. L. (2010). Knowledge management, human resource management, and higher education: a theoretical model. Journal of Education for Business, 85(6), 330-335.

Brief, A. P., \& Weiss, H. M. (2002). Organizational behavior: Affect in the workplace. Annual review of psychology, 53(1), 279-307. https:/doi.org/10.1146/annurev.psych.53.100901.135156

Clarke, R., \& Keating, W. F. (1995). A Fresh Look at Teacher Job Satisfaction.Paper presented at the Annual Meeting of the National Council of States on Inservice Education, Anaheim, CA, November $7^{\text {th }}$, ERIC, pp. $1-16$.

Cricelli, L., Grimaldi, M., \& Hanandi, M. (2012). Innovation and IT in Knowledge Management to Enhance Learning and Assess Human Capital. Knowledge Management Innovations for Interdisciplinary Education: Organizational Applications, 18, 366-383.

Crossman, A., \& Abou-Zaki, B. (2003). Job satisfaction and employee performance of Lebanese banking staff. Journal of Managerial Psychology, 18(4), 368-376. http://dx.doi.org/10.1108/02683940310473118

Fisher, C. D. (2000). Mood and emotions while working: Missing pieces of job satisfaction. Journal of organizational behavior, 21(2), 185-202. Retrieved from http://www.jstor.org/stable/3100305

Fugate, B. S., Stank, T. P., \& Mentzer, J. T. (2009). Linking improved knowledge management to operational and organizational performance. Journal of Operations Management, 27(3), 247-264. http://dx.doi.org/10.1016/j.jom.2008.09.003

Gasquet, I., Falissard, B., \& Ravaud, P. (2001). Impact of reminders and method of questionnaire distribution on patient response to mail-back satisfaction survey. Journal of clinical epidemiology, 54(11), 1174-1180. http://dx.doi.org/10.1016/S0895-4356(01)00387-0 
Gloet, M. (2006). Knowledge management and the links to HRM: Developing leadership and management capabilities to support sustainability. Management Research News, 29(7), 402-413. https:/doi.org/10.1108/01409170610690862

Guerra, G., \& Patuelli, R. (2014). The Role of Job Satisfaction in Transitions Into Self - Employment. Entrepreneurship Theory and Practice, 40, 543-571. https:/doi.org/10.1111/etap.12133

Hansen, M. T., Nohria, N., \& Tierney, T. (1999). What's your strategy for managing knowledge? The knowledge management yearbook 2000-2001, 55-69.

Hau, Y. S., Kim, B., Lee, H., \& Kim, Y.-G. (2013). The effects of individual motivations and social capital on employees' tacit and explicit knowledge sharing intentions. International Journal of Information Management, 33(2), 356-366. http://dx.doi.org/10.1016/j.ijinfomgt.2012.10.009

Herzberg, F., Mausnes, B., Peterson, R. O., \& Capwell, D. F. (1957). Job attitudes; review of research and opinion. pp. 259.

Hislop, D. (2002). Mission impossible? Communicating and sharing knowledge via information technology. Journal of Information Technology, 17(3), 165-177. https:/doi.org/10.1080/02683960210161230

Hodson, R. (1989). Gender differences in job satisfaction. The Sociological Quarterly, 30(3), 385-399. DOI: 10.1111/j.1533-8525.1989.tb01527.x

Huysman, M., \& De Wit, D. (2004). Practices of managing knowledge sharing: towards a second wave of knowledge management. Knowledge and process management, 11(2), 81-92. https:/doi.org/10.1002/kpm.192

Islam, J., Quazi, A., \& Rahman, A. (2011). Nexus between cultural dissonance, management accounting systems and managerial effectiveness: Evidence from an Asian developing country, Journal of Asia Pacific Business, 12(3), 280-303. http://dx.doi.org/10.1080/10599231.2011.577989

Jimenez-Jimenez, D., \& Sanz-Valle, R. (2012). Studying the effect of HRM practices on the knowledge management process. Personnel Review, 42(1), 28-49. http://dx.doi.org/10.1108/00483481311285219

Katou, A. A., \& Budhwar, P. S. (2010). Causal relationship between HRM policies and organisational performance: Evidence from the Greek manufacturing sector. European management journal, 28(1), 25-39. http://dx.doi.org/10.1016/j.emj.2009.06.001

Khan, A. R., Hasan, N., \& Rubel, M. (2015). Factors Affecting Organizations Adopting Human Resource Information Systems: A Study in Bangladesh. IOSR Journal of Business and Management, 17(11(2)), 45-54. https:/doi.org/10.9790/487X-171124554

Lindner, F., \& Wald, A. (2011). Success factors of knowledge management in temporary organizations. $\begin{array}{llll}\text { International Journal of project management, } & \text { 29(7), } & \text { 877-888. }\end{array}$ http://dx.doi.org/10.1016/j.ijproman.2010.09.003

Maidani, E. A. (1991). Comparative study of Herzberg's two-factor theory of job satisfaction among public and private sectors. Public Personnel Management, 20(4), 441-448.

Mas-Machuca, M., \& Martínez Costa, C. (2012). Exploring critical success factors of knowledge management projects in the consulting sector. Total Quality Management \& Business Excellence, 23(11-12), 1297-1313. http://dx.doi.org/10.1080/14783363.2011.637778

Mia, M. A. H., \& Hasan, N. (2016). Impact of knowledge management on organizational Performance-An Exploratory Study in Bangladesh. Bangladesh Journal of MIS, 7(2), 1-21.

Mills, A. M., \& Smith, T. A. (2011). Knowledge management and organizational performance: a decomposed view. Journal of Knowledge Management, 15(1), 156-171. http://dx.doi.org/10.1108/13673271111108756

Moideenkutty, U., Al-Lamki, A., \& Sree Rama Murthy, Y. (2011). HRM practices and organizational performance in Oman. Personnel Review, 40(2), 239-251. http://dx.doi.org/10.1108/00483481111106101

Moorman, R. H., Niehoff, B. P., \& Organ, D. W. (1993). Treating employees fairly and organizational citizenship behavior: Sorting the effects of job satisfaction, organizational commitment, and procedural justice. Employee responsibilities and rights journal, 6(3), 209-225. https:/doi.org/10.1007/BF01419445

Nielsen, P., Rasmussen, P., Fong, C.-Y., Ooi, K.-B., Tan, B.-I., Lee, V.-H., \& Yee-Loong Chong, A. (2011). HRM practices and knowledge sharing: an empirical study. International Journal of Manpower, 32(5/6), 704-723. http://dx.doi.org/10.1108/01437721111158288 
Prihandinisari, C., Rahman, A. \& Hicks, J. (2016). What motivate individuals to join public service? Examining Public Service Motivation in a non-western cultural context. In Proceedings of 5th Global Business and Finance Research Conference 2 - 3 June, Sydney, pp. 1-13.

Rahman, A. (2016). Small area housing stress estimation in Australia: Calculating confidence intervals for a spatial microsimulation model. Communications in Statistics - Simulation and Computation, (in press), pp. 1-19. http://dx.doi.org/10.1080/03610918.2016.1241406

Rahman, A. and Harding, A. (2016). Small area estimation and microsimulation modelling. Chapman \& Hall/CRC, FL.

Rahman, A., Gao, J., D'Este, C. and Ahmed, S.E. (2016). An assessment of the effects of prior distributions on the Bayesian predictive inference. International Journal of Statistics and Probability, 5(5), 1-12. http://dx.doi.org/10.5539/ijsp.v5n5p31

Rao, L., Mansingh, G., \& Osei-Bryson, K.-M. (2012). Building ontology based knowledge maps to assist business process re-engineering. Decision Support Systems, 52(3), 577-589. http://dx.doi.org/10.1016/j.dss.2011.10.014

Runar Edvardsson, I. (2008). HRM and knowledge management. Employee Relations, 30(5), 553-561. http://dx.doi.org/10.1108/01425450810888303

Salisbury, M. W. (2003). Putting theory into practice to build knowledge management systems. Journal of Knowledge Management, 7(2), 128-141. http://dx.doi.org/10.1108/13673270310477333

Schuler, R. S., \& Jackson, S. E. (1987). Linking competitive strategies with human resource management practices. The Academy of Management Executive (1987-1989), 207-219. Retrieved from http://www.jstor.org/stable/4164753

Silwattananusarn, T., \& Tuamsuk, K. (2012). Data mining and its applications for knowledge management: A literature review from 2007 to 2012. arXiv preprint arXiv:1210.2872.

Tan, C. L., \& Nasurdin, A. M. (2011). Human resource management practices and organizational innovation: assessing the mediating role of knowledge management effectiveness. Electronic Journal of Knowledge Management, 9(2), 155-167.

Villar, C., Alegre, J., \& Pla-Barber, J. (2014). Exploring the role of knowledge management practices on exports: A dynamic capabilities view. International Business Review, 23(1), 38-44. http://dx.doi.org/10.1016/j.ibusrev.2013.08.008

Zheng, W., Yang, B., \& McLean, G. N. (2010). Linking organizational culture, structure, strategy, and organizational effectiveness: Mediating role of knowledge management. Journal of Business research, 63(7), 763-771. http://dx.doi.org/10.1016/j.jbusres.2009.06.005

Zhou, K. Z., \& Li, C. B. (2012). How knowledge affects radical innovation: Knowledge base, market knowledge acquisition, and internal knowledge sharing. Strategic Management Journal, 33(9), 1090-1102. https:/doi.org/10.1002/smj.1959

Zucker, L. G., Darby, M. R., \& Armstrong, J. S. (2002). Commercializing knowledge: University science, knowledge capture, and firm performance in biotechnology. Management Science, 48(1), 138-153. http://dx.doi.org/10.1287/mnsc.48.1.138.14274

\begin{tabular}{llllll}
\hline & Original \\
Appendix 1: Path Coefficient & Sample & Mample & $\begin{array}{l}\text { Standard } \\
\text { Deviation }\end{array}$ & $\begin{array}{l}\text { Standard } \\
\text { Error }\end{array}$ & T Statistics \\
\hline HRM Practice -> organizational performance & 0.6211 & 0.6275 & 0.0802 & 0.0802 & 7.7496 \\
Job Satisfaction -> Job Loyalty & 0.5838 & 0.5921 & 0.0877 & 0.0877 & 6.6605 \\
KM Practice -> HRM Practice & 0.286 & 0.3211 & 0.1254 & 0.1254 & 2.2809 \\
KM Practice -> organizational performance & 0.0041 & 0.0004 & 0.0906 & 0.0906 & 0.0452 \\
Organizational performance -> Job Satisfaction & 0.5044 & 0.5102 & 0.0812 & 0.0812 & 6.2092 \\
HRMP1 <- HRM Practice & 0.4367 & 0.4268 & 0.1659 & 0.1659 & 2.6325 \\
HRMP2 <- HRM Practice & 0.3919 & 0.3723 & 0.1757 & 0.1757 & 2.2305 \\
\hline
\end{tabular}




\begin{tabular}{llllll}
\hline HRMP3 <- HRM Practice & 0.6764 & 0.6577 & 0.129 & 0.129 & 5.2432 \\
HRMP4 <- HRM Practice & 0.7766 & 0.7592 & 0.0765 & 0.0765 & 10.1531 \\
HRMP5 <- HRM Practice & 0.5848 & 0.5755 & 0.105 & 0.105 & 5.5675 \\
HRMP6 <- HRM Practice & 0.7194 & 0.7217 & 0.0731 & 0.0731 & 9.8412 \\
JL1 <- Job Loyalty & 0.9007 & 0.8995 & 0.0299 & 0.0299 & 30.0795 \\
JL2 <- Job Loyalty & 0.8826 & 0.8822 & 0.0272 & 0.0272 & 32.4873 \\
JS1 <- Job Loyalty & 0.881 & 0.8778 & 0.0353 & 0.0353 & 24.9483 \\
JS2 <- Job Loyalty & 0.8607 & 0.8589 & 0.0377 & 0.0377 & 22.8027 \\
JS3 <- Job Loyalty & 0.8546 & 0.8564 & 0.0275 & 0.0275 & 31.1087 \\
KM1 <- KM Practice & 0.7784 & 0.7431 & 0.1774 & 0.1774 & 4.3883 \\
KM2 <- KM Practice & 0.8562 & 0.8265 & 0.1702 & 0.1702 & 5.0297 \\
KM3 <- KM Practice & 0.7777 & 0.7525 & 0.1388 & 0.1388 & 5.6049 \\
KM4 <- KM Practice & 0.8252 & 0.7727 & 0.1634 & 0.1634 & 5.0488 \\
KM5 <- KM Practice & 0.6439 & 0.5969 & 0.1583 & 0.1583 & 4.0668 \\
OP1 <- organizational performance & 0.7471 & 0.7465 & 0.0587 & 0.0587 & 12.7306 \\
OP2 <- organizational performance & 0.8221 & 0.8223 & 0.0382 & 0.0382 & 21.5359 \\
OP3 <- organizational performance & 0.7732 & 0.7705 & 0.0428 & 0.0428 & 18.0629 \\
OP4 <- organizational performance & 0.8715 & 0.8704 & 0.024 & 0.024 & 36.3861 \\
\hline
\end{tabular}

\section{Copyrights}

Copyright for this article is retained by the author(s), with first publication rights granted to the journal.

This is an open-access article distributed under the terms and conditions of the Creative Commons Attribution license (http://creativecommons.org/licenses/by/4.0/). 